\title{
Analisis Model Prediksi Kebangkrutan Industri Garmen dengan Menggunakan Metode Altman Z- Score
}

\author{
Fajar Pratama ${ }^{1}$, Bramantiyo Eko Putro ${ }^{2}$ \\ ${ }^{1,2}$ Teknik Industri Universitas Suryakancana \\ Jl. Pasir Gede Raya, Bojongherang, Cianjur \\ ${ }^{1}$ zoeytama@gmail.com, ${ }^{2}$ bramantiyoep91@gmail.com
}

Dikirimkan: 10, 2017 . Diterima: 12, 2017. Dipublikasikan: 12, 2017.

\begin{abstract}
PT. Eastern Modern Apparel is engaged in garment production. The company has experienced financial constraints. This is marked by the dismissal of some employees. Research is done to determine the prediction of bankruptcy of the company. Methodology that has been done in this research are conducting interviews with the company, field study, financial data retrieval. The step is done to meet the data needs in the next step. The next step is data processing using Altman Z-Score method. Processing consists of XI= Working Capital Ratio against Total Assets, X2 = Retained Earnings Ratio against Total Assets, X3 =EBIT Ratio against Total Assets, X4 = Market Equity Value Threshold on Book Value of Debt. X5 = Sales to Total Assets. Processed data is in the period 2014, 2015, and 2016. The process produces Z-Score value for each period. Z-Score calculation results in the period $2014=3.91,2015=3.19$, and $2016=2.83$. While the limits of healthy company according to calculations Almant Z-Score of $>2.675$. Then the results of Altman Z-Score calculations on the company is said to be healthy, because the results exceed the limits of the healthy category. However there is a decrease of each period.

Keywords: Corporate Financial Performance, Altman Z-Score, Healthy Company
\end{abstract}

\begin{abstract}
Abstrak - PT. Eastern Modern Apparel bergerak dalam bidang produksi garmen. Perusahaan tersebut pernah mengalami kendala dalam bidang finansial. Hal ini ditandai dengan adanya pemberhentian beberapa pegawai. Penelitan dilakukan untuk mengetahui prediksi kebangkrutan perusahaan tersebut. Langkah yang dilakukan dalam penelitian yaitu: melakukan wawancara dengan pihak perusahaan, studi lapangan, pengambilan data finansial. Langkah tersebut dilakukan untuk memenuhi kebutuhan data pada langkah selanjutnya. Langkah selanjutnya dilakukan pengolahan data dengan menggunakan metode Altman Z-Score. Pengolahan tersebut terdiri dari $\mathrm{X}_{1}=$ Rasio Modal Kerja terhadap Total Aktiva, $\mathrm{X}_{2}=$ Rasio Laba Ditahan terhadap Total Aktiva, $\mathrm{X}_{3}=$ Rasio EBIT terhadap Total Aktiva, X4 = Nilai Pasar Ekuitas terhadap Nilai Buku Hutang. X5 = Penjualan terhadap Total Aktiva. Data yang diolah yaitu pada periode tahun 2014, 2015, dan 2016. Proses tersebut menghasilkan nilai Z-Score untuk masing-masing periode. Hasil perhitungan ZScore pada periode tahun $2014=3,91$, tahun $2015=3,19$, dan tahun $2016=2,83$. Sedangkan batasan kategori perusahaan sehat menurut perhitungan Almant Z-Score sebesar $>2,675$. Maka hasil perhitungan Altman Z-Score pada perusahaan tersebut dikatakan sehat, karena hasil tersebut melebihi batasan kategori sehat. Namun terjadi penurunan dari masing-masing periode.
\end{abstract}

Kata Kunci: Kinerja Finansial Perusahaan, Altman Z-Score, Perusahaan Sehat

\section{PENDAhUluan}

Kelayakan pabrik adalah penelitian tentang mampu atau tidaknya suatu perusahaan dijabarkan dengan berhasil atau tidaknya berdasarkan pertimbangan manfaat finansial [1]. Adapun definisi yang lain, studi kelayakan perusahaan adalah penelitian tentang berhasil tidaknya proyek investasi yang dilaksanakan [2]. Studi kelayakan pabrik sangat diperlukan oleh banyak kalangan, terutama bagi investor selaku pemrakarsa perusahaan. Hal ini juga yang harus diperhatikan pemilik perusahaan sekaligus investor, dalam usahanya diperlukan pertimbangan-pertimbangan tertentu karena di dalam studi kelayakan terdapat aspek yang harus dikaji yaitu aspek finansial.

Perusahaan mempunyai tujuan finansial jangka pendek dan jangka panjang, memperoleh keuntungan dari hasil pendapatan atau penjualan yang sudah dikurangi dari biaya-biaya yang 
dikeluarkan merupakan tujuan jangka pendek perusahaan. Pengembangan atau peningkatan nilai perusahaan dengan menggunakan pendapatan atau keuntungan yang telah diperoleh perusahaan demi mempertahankan keberlangsungan perusahaan adalah tujuan jangka panjang perusahaan. Selain tujuan tersebut keberhasilan manajemen dalam menjalankan sebuah perusahaan merupakan daya tarik bagi investor untuk bekerja sama dengan perusahaan.

Keberhasilan tidak selalu diperoleh karena beberapa perusahaan mengalami kesulitan keuangan dan dinyatakan bangkrut, hal ini dapat disebabkan oleh gagalnya manajemen perusahaan ataupun bencana alam seperti kebakaran, gempa bumi dan bencana alam yang lainnya. Potensi kebangkrutan yang dimiliki oleh setiap perusahaan akan memberi kekhawatiran bagi berbagai pihak pada sektor internal seperti manajer dan karyawan, maupun pihak eksternal perusahaan seperti: investor dan kreditur. Pihak investor dimungkinkan kehilangan saham yang ditanamkan pada perusahaan tersebut dan pihak kreditur akan mengalami kerugian karena telah meminjamkan modal yang tidak bisa dilunasi oleh pihak perusahaan (tak tertagih).

Kebangkrutan merupakan kegagalan perusahaan dalam menjalankan perusahaan untuk menghasilkan laba. Kebangkrutan juga sering disebut likuidasi perusahaan atau penutupan perusahaan atau insolvabilitas [3]. Oleh karena itu prediksi kebangkrutan berfungsi untuk memberikan panduan kepada pihak-pihak yang berkepentingan tentang kinerja keuangan perusahaan apakah akan mengalami kesulitan keuangan atau tidak di masa mendatang. Semakin awal tanda-tanda kebangkrutan diketahui maka akan semakin baik karena manajemen dapat melakukan perbaikan-perbaikan. Pihak kreditur dan pemegang saham juga dapat melakukan persiapan untuk mengatasi berbagai kemungkinan yang buruk.

Indikator-indikator yang dapat digunakan untuk melihat tanda-tanda kebangkrutan dibagi menjadi dua [4], yaitu dapat diamati pihak ekstern, seperti: Penurunan laba secara terus menerus, pemecatan pegawai besar-besaran, dan beberapa faktor lainnya. Indikator juga dapat diamati pihak intern (perusahaan), seperti: Ketergantungan terhadap utang, turunnya kemampuan dalam mencetak keuntungan, serta turunnya volume penjualan. Informasi tentang prediksi kebangkrutan suatu perusahaan akan sangat bermanfaat bagi beberapa kalangan [5]. PT. Eastern Modern Apparel pernah mengalami beberapa kondisi yang mendekati kebangkrutan yaitu. Hal tersebut membuat PT. Eastern Modern Apparel melakukan pemberhentian pada beberapa karyawan yang dikarenakan gejala (kebangkrutan) tersebut terjadi pada lini produksi yang berdampak pada manajemen keuangan perusahaan. Oleh karena itu pihak manajemen mempunyai keinginan untuk membenahi atau menganalisis tentang kelayakan perusahaan.

PT. Panasia Indosyntex merupakan perusahaan yang kurang diminati oleh para investor. Hal ini dapat ditunjukkan dengan pergerakan saham yang kurang baik yaitu penurunan yang signifikan. Selain itu, PT Century Textile Industry yang bergerak dalam bidang yang sama yaitu garmen juga dijadikan sebagai perusahaan pembanding. Oleh karena itu diambil rumusan masalah sebagai berikut :

1. Apakah perusahaan garmen (PT EMA, PT Syntex, PT Centex) mengalami financial disstress berdasarkan metode Altman ZScore periode 2014 - 2016 ?

2. Apa trend kondisi keuangan yang dialami perusahaan garmen di Indonesia pada periode 2014 - 2016 ?

Penelitian ini bertujuan untuk mengetahui apakah perusahaan garmen (PT EMA, PT Syntex, PT Centex) mengalami financial disstress menggunakan metode altman Z-score periode 2014 - 2016. Selain itu penelitian ini berusaha mengetahui trend kondisi keuangan yang dialami perusahaan garmen di Indonesia pada periode $2014-2016$.

\section{Metodologi Penelitian}

Tahapan pertama yang peneliti lakukan adalah mengidentifikasi masalah, dengan datang langsung ke PT. Eastern Modern Apparel. Hal ini dilakukan untuk mengetahui informasi tentang masalah yang akan diteliti serta melihat kelayakan perusahaan tersebut sehingga dalam penyelesaian masalah peneliti tidak mengalami kendala yang berarti. Permasalahan yang akan dibahas dilihat dari aspek finansial. Penelitian ini diarahkan untuk mengetahui kelayakan finansial. Sehingga dapat dinilai layak atau tidaknya usaha tersebut untuk dilanjutkan. Dalam mengembangkan usaha pada perusahaan garmen. Maka terlebih dahulu diidentifikasi karakteristik usaha tersebut dengan melihat berbagai aspek. Pengambilan data tersebut dilakukan secara sekunder yang menghasilkan permasalahan dalam aspek finansial. Selain itu dilakukan juga pengambilan data dengan cara mempelajari dan memahami teori yang berhubungan dengan analisis prediksi kebangkrutan metode Altman Z-Score dari literatur, jurnal, media masa dan hasil penelitian yang diperoleh dari berbagai sumber.

Setelah permasalahan ditentukan langkah selanjutnya adalah mengumpulkan data-data dari 
perusahaan yaitu: melakukan wawancara langsung dengan HRD dan karyawan pabrik, observasi langsung di pabrik, dan searching internet. Data yang diambil berupa data sekunder yang merupakan laporan finansial. Laporan tersebut diambil dari (PT EMA, PT Syntex, PT Centex) selama 3 periode. Jika ada data yang tidak bisa didapatkan dari perusahaan maka peneliti melakukan asumsi terhadap data tersebut. Setelah data-data yang diperlukan didapat dilakukan pengolahan data. Pengolahan data berisi data laporan finansial perusahaan dan mencari solusi perbaikan kelayakan usaha $P T$. Eastern Modern Apparel. Tujuan penelitian ini adalah untuk menganalisis kelayakan usaha pakaian pada perusahaan (PT EMA, PT Syntex, PT Centex), penelitian dianalisis secara kuantitatif meliputi aspek-aspek finansial, untuk menganalisis risiko terjadinya kebangkrutan di (PT EMA, PT Syntex, PT Centex) dengan menggunakan metode penelitian $Z$ - Score Altman. Model prediksi kebangkrutan Altman (1983) Z-score merupakan suatu metode untuk memprediksi kesehatan financial suatu perusahaan dan kemungkinan untuk mengalami kebangkrutan. rumus yang telah direvisi Altman tahun 1983 inilah yang akan digunakan dalam penelitian ini yaitu:

$$
\begin{aligned}
& \text { Z- score }=0,717 \mathrm{X}_{1}+0,874 \mathrm{X}_{2}+3,107 \mathrm{X}_{3}+ \\
& 0,420 \mathrm{X}_{4}+0,998 \mathrm{X}_{5} \text {. } \\
& \text { Di mana: } \\
& \mathrm{X}_{1}=\text { Rasio Modal Kerja terhadap Total Aktiva. } \\
& \mathrm{X}_{2}=\text { Rasio Laba Ditahan terhadap Total Aktiva. } \\
& \mathrm{X}_{3}=\text { Rasio EBIT Terhadap Total Aktiva. } \\
& \mathrm{X}_{4}=\text { Nilai Pasar Ekuitas terhadap Nilai Buku } \\
& \text { Hutang. } \\
& \text { X5 = Penjualan Terhadap Total Aktiva. }
\end{aligned}
$$

Jika $Z>2,675$ maka perusahaan dinyatakan sehat, jika $Z<1,81$ maka perusahaan berpotensi bangkrut, namun jika Z- Score di antara 1,81 2,675 perusahaan berada pada kondisi abu-abu (grey area).

\section{HAsil PENELITIAN}

- $\mathrm{X}_{1}$ (Working Capital to Total Assets) ini menunjukkan kemampuan perusahaan untuk menghasilkan modal kerja bersih dari keseluruhan total aktiva (assets). Data diperoleh dengan cara aktiva lancar dikurangi dengan kewajiban lancar.

- $\mathrm{X}_{2}$ (Retained Earning to Total Assets) Rasio ini menunjukkan kemampuan perusahaan untuk menghasilkan laba di tahan dari total aktiva perusahaan. Laba ditahan merupakan

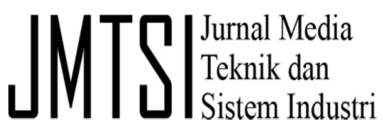

laba yang tidak dibagikan kepada para pemegang saham.

- $\mathrm{X}_{3}$ (EBIT to Total Assets) kemampuan perusahaan untuk menghasilkan laba dari aktiva perusahaan, sebelum pembayaran bunga.

- $\mathrm{X}_{4}$ (Market Value Of Equity to Book Value of Total Liabilities) menunjukkan kemampuan

\begin{tabular}{|c|c|c|c|}
\hline \multicolumn{4}{|c|}{ Tahun } \\
\hline Working Capita & 14 & 15 & 16 \\
\hline PT.EMA & 22,273 & 22,273 & 22,273 \\
\hline CENTEX & 20,811 & 20,811 & 20,811 \\
\hline SYNTEX & 19,351 & 19,351 & 19,351 \\
\hline \multicolumn{4}{|c|}{ Total Asset } \\
\hline PT.EMA & 36.435 & 50.838 & 65.467 \\
\hline CENTEX & 35,07 & 39,564 & 41,782 \\
\hline SYNTEX & 39,221 & 48,382 & 68,455 \\
\hline \multicolumn{4}{|c|}{ Laba Ditahan } \\
\hline PT.EMA & 13,923 & 28,385 & 43,073 \\
\hline CENTEX & 11,993 & 19,478 & 22,006 \\
\hline SYNTEX & 9,993 & 16,467 & 21,459 \\
\hline \multicolumn{4}{|c|}{ EBIT } \\
\hline PT.EMA & 20,466 & 20,197 & 20,545 \\
\hline CENTEX & 21,427 & 22,123 & 22,705 \\
\hline SYNTEX & 19,899 & 19,568 & 20,023 \\
\hline \multicolumn{4}{|c|}{ Harga Saham Bursa } \\
\hline PT.EMA & 0,002 & 0,026 & 0,083 \\
\hline CENTEX & 0,038 & 0,045 & 0,088 \\
\hline SYNTEX & 0,011 & 0,013 & 0,016 \\
\hline \multicolumn{4}{|c|}{ Total Hutang } \\
\hline PT.EMA & 2,027 & 2,169 & 2,412 \\
\hline CENTEX & 1,882 & 1,991 & 2,231 \\
\hline SYNTEX & 1,725 & 1,583 & 1,943 \\
\hline \multicolumn{4}{|c|}{ Penjualan } \\
\hline PT.EMA & 28,819 & 28,613 & 29,105 \\
\hline CENTEX & 31,944 & 32,874 & 35,671 \\
\hline SYNTEX & 27,991 & 35,562 & 35,99 \\
\hline
\end{tabular}
perusahaan untuk memenuhi kewajibankewajiban dari nilai pasar modal sendiri (saham biasa).

- $\mathrm{X}_{5}$ (Sales to Total Assets) menghasilkan volume bisnis yang cukup dibandingkan investasi dalam total aktivanya.

TABEL I

Data Penelitian

Berdasarkan tabel 1 dapat dilihat Modal kerja dan total asset. Sehingga variabel X1 dapat dihitung dalam metode Z-score sebagai berikut:

PT. Eastern Modern Apparel.

$\begin{array}{lll}\text { Tahun } & 2014 & 22,273 / 36,435=0,611 \\ & 2015 & 22,273 / 50,838=0,438 \\ & 2016 & 22,273 / 65,467=0,340\end{array}$

PT. Century Textile Industri

Tahun $2014 \quad 20,811 / 35,070=0,593$

$201520,811 / 39,564=0,526$ 
Pratama \& Putro

$2016 \quad 20,811 / 41,782=0,498$

PT. Panisia Indosyntex

$\begin{array}{lll}\text { Tahun } & 2014 & 19,351 / 39,221=0,493 \\ & 2015 & 19,531 / 48,382=0,400 \\ & 2016 & 19,531 / 68,455=0,283\end{array}$

Berdasarkan tabel 1 dapat dilihat laba ditahan dan total asset. Sehingga variabel X2 dapat dihitung dalam metode Z-score sebagai berikut: PT. Eastern Modern Apparel.

$\begin{array}{lll}\text { Tahun } & 2014 & 13,923 / 36,435=0,382 \\ & 2015 & 28,385 / 50,838=0,558 \\ & 2016 & 43,073 / 65,467=0,658\end{array}$

PT. Century Textile Industri

$\begin{array}{lll}\text { Tahun } & 2014 & 11,993 / 35,070=0,342 \\ & 2015 & 19,478 / 39,564=0,492 \\ & 2016 & 22,006 / 41,782=0,527\end{array}$

PT. Panisia Indosyntex

$\begin{array}{lll}\text { Tahun } & 2014 & 9,993 / 39,221=0,255 \\ & 2015 & 16,467 / 48,382=0,340 \\ & 2016 & 21,459 / 68,455=0,313\end{array}$

Berdasarkan tabel 1 dapat dilihat laba ditahan dan total asset. Sehingga variabel X3 dapat dihitung dalam metode Z-score sebagai berikut:

PT. Eastern Modern Apparel.

$\begin{array}{lll}\text { Tahun } & 2014 & 20,466 / 36,435=0,562 \\ & 2015 & 20,197 / 50,838=0,397 \\ & 2016 & 20,545 / 65,467=0,314\end{array}$

PT. Century Textile Industri

$\begin{array}{lll}\text { Tahun } & 2014 & 21,427 / 35,070=0,611 \\ & 2015 & 22,123 / 39,564=0,559 \\ & 2016 & 22,705 / 41,782=0,543\end{array}$

PT. Panisia Indosyntex

$$
\begin{array}{lll}
\text { Tahun } & 2014 & 19,899 / 39,221=0,507 \\
& 2015 & 19,568 / 48,382=0,404 \\
& 2016 & 20,083 / 68,455=0,293
\end{array}
$$

Berdasarkan tabel 1 dapat dilihat harga pasar saham dan total hutang. Sehinga variabel X4 dapat dihitung dalam metode Z-score sebagai berikut:

PT. Eastern Modern Apparel.

$$
\begin{array}{lll}
\text { Tahun } & 2014 & 0,002 / 2,027=0,001 \\
& 2015 & 0,026 / 2,169=0,012
\end{array}
$$

$$
2016 \quad 0,083 / 2,412=0,034
$$

PT. Century Textile Industri

$$
\begin{array}{lll}
\text { Tahun } & 2014 & 0,038 / 1,882=0,020 \\
& 2015 & 0,045 / 1,991=0,023 \\
& 2016 & 0,088 / 2,231=0,039
\end{array}
$$

PT. Panisia Indosyntex

$$
\begin{array}{lll}
\text { Tahun } & 2014 & 0,011 / 1,725=0,006 \\
& 2015 & 0,013 / 1,583=0,008 \\
& 2016 & 0,016 / 1,943=0,008
\end{array}
$$

Berdasarkan tabel 1 dapat dilihat penjualan dan total hutang. Sehingga variabel X5 dapat dihitung dalam metode Z-score sebagai berikut: PT. Eastern Modern Apparel.

$$
\begin{array}{lll}
\text { Tahun } & 2014 & 28,819 / 36,435=0,791 \\
& 2015 & 28,613 / 50,838=0,563 \\
& 2016 & 29,105 / 65,467=0,445
\end{array}
$$

PT. Century Textile Industri

$$
\begin{array}{lll}
\text { Tahun } & 2014 & 31,944 / 35,070=0,911 \\
& 2015 & 32,874 / 39,564=0,831 \\
& 2016 & 35,671 / 41,782=0,854
\end{array}
$$

PT. Panisia Indosyntex

$$
\begin{array}{lll}
\text { Tahun } & 2014 & 27,991 / 39,221=0,714 \\
& 2015 & 27,991 / 50,838=0,735 \\
& 2016 & 35,990 / 68,455=0,526
\end{array}
$$

Proses dan hasil model analisis Altman ZScore Tahun 2014:

$Z=1.2 X_{1}+1.4 X_{2}+3.3 X_{3}+0.6 X_{4}+0.999 X_{5}$

PT. Eastern Modern Apparel.

$1,2(0,611)+1,4(0,382)+3,3(0,562)+0,6$ $(0,001)+0,999(0,791)=3,91$

PT. Century Textile Industri

$1,2(0,593)+1,4(0,342)+3,3(0,611)+0,6$ $(0,020)+0,999(0,991)=4,13$

PT. Panisia Indosyntex $1,2(0,493)+1,4(0,255)+3,3(0,507)+0,6$ $(0,006)+0,999(0,714)=3,34$

Proses dan Hasil Model Analisis Altman ZScore Tahun 2015:

PT. Eastern Modern Apparel

$1,2(0,438)+1,4(0,558)+3,3(0,397)+0,6$ $(0,012)+0,999(0,563)=3,19$ 
PT. Century Textile Industri

$1,2(0,526)+1,4(0,492)+3,3(0,559)+0,6$

$(0,023)+0,999(0,831)=4,01$

PT. Panisia Indosyntex

$1,2(0,400)+1,4(0,340)+3,3(0,404)+0,6$

$(0,008)+0,999(0,735)=3,03$

Proses dan Hasil Model Analisis Altman ZScore Tahun 2016:

PT. Eastern Modern Apparel.

$1,2(0,340)+1,4(0,658)+3,3(0,314)+0,6$

$(0,034)+0,999(0,445)=2,83$

PT. Century Textile Industri

$1,2(0,498)+1,4(0,527)+3,3(0,543)+0,6$

$(0,039)+0,999(0,854)=4,00$

PT. Panisia Indosyntex

$1,2(0,283)+1,4(0,313)+3,3(0,292)+0,6$

$(0,008)+0,999(0,526)=2,27$

Dari hasil perhitungan kelima rasio di atas dikalikan dengan standar masing-masing sesuai dengan ketentuan Z-score maka akan diperoleh hasil Z-score untuk PT.Eastern Modern Apparel dan perusahaan pembanding pada tahun 2014 2016, yaitu sebagai berikut:

TABEL II

HASIL Z-SCORE TAHUN 2014

\begin{tabular}{|l|l|l|l|l|l|l|l|}
\hline No & Nama Perusahaan & $\mathrm{X}_{1}$ & $\mathrm{X}_{2}$ & $\mathrm{X}_{3}$ & $\mathrm{X}_{4}$ & $\mathrm{X}_{5}$ & Z-score \\
\hline 1 & PT. Eastm Modern Apparel & 0,611 & 0,382 & 0,562 & 0,001 & 0,791 & 3,91 \\
\hline 2 & PT. Century Textile Industri & 0,593 & 0,342 & 0,611 & 0,020 & 0,991 & 4,13 \\
\hline 3 & PT. Panisia Indosyntex & 0,493 & 0,255 & 0,507 & 0,006 & 0,714 & 3,34 \\
\hline
\end{tabular}

Berdasarkan tabel II terlihat bahwa hasil Zscore diatas perusahaan berada dalam kondisi yang sehat menurut $Z$-score ditandai dengan nilai hasilnya yang berada diatas 2,675

TABEL III

HASIL Z-SCORE TAHUN 2015

\begin{tabular}{|l|l|l|l|l|l|l|l|}
\hline No & Nama Perusahaan & $\mathrm{X}_{1}$ & $\mathrm{X}_{2}$ & $\mathrm{X}_{3}$ & $\mathrm{X}_{4}$ & $\mathrm{X}_{5}$ & Z-score \\
\hline 1 & PT. Eastrn Modern Apparel & 0,438 & 0,558 & 0,397 & 0,012 & 0,563 & 3,19 \\
\hline 2 & PT. Century Textile Industri & 0,526 & 0,492 & 0,559 & 0,023 & 0,831 & 4,01 \\
\hline 3 & PT. Panisia Indosyntex & 0,400 & 0,340 & 0,404 & 0,008 & 0,735 & 3,03 \\
\hline
\end{tabular}

Berdasarkan tabel III terlihat bahwa ada salah satu perusahaan berada dalam kondisi abu - abu (grey area) menurut Z-score ditandai dengan nilai hasilnya yang berada di antara 1,81 - 2,675.

Berdasarkan tabel IV maka dapat disimpulkan bahwa PT. Eastern Modern Apparel masih dalam kondisi yang sehat menurut Z-score namun meski dalam kondisi sehat tiap periode mengalami penurunan. Penurunan kondisi yang

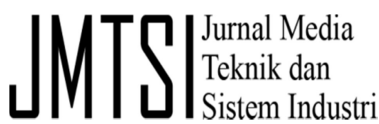

terparah terjadi pada tahun 2016, yang nilainya hampir mendekati kondisi grey area. Maka dari itu disarankan bahwa PT. Eastern Modern Apparel harus mengontrol segala sumber daya yang ada di perusahaan terutama dalam hal keuangan.

TABEL IV

HASIL Z-SCORE TAHUN 2016

\begin{tabular}{|l|l|l|l|l|l|l|l|}
\hline No & Nama Perusahaan & $\mathrm{X}_{1}$ & $\mathrm{X}_{2}$ & $\mathrm{X}_{3}$ & $\mathrm{X}_{4}$ & $\mathrm{X}_{5}$ & Z-score \\
\hline 1 & PT. Eastrn Modern Apparel & 0,340 & 0,658 & 0,314 & 0,034 & 0,445 & 2,83 \\
\hline 2 & PT. Century Textile Industri & 0,498 & 0,527 & 0,543 & 0,039 & 0,854 & 4,00 \\
\hline 3 & PT. Panisia Indosyntex & 0,283 & 0,313 & 0,292 & 0,008 & 0,526 & 2,27 \\
\hline
\end{tabular}

Hasil prediksi dari pengolahan data dapat dilihat pada tabel V berikut ini.

TABEL V

PREDIKSI KEBANGKRUTAN PADA TAHUN 2014-2016

\begin{tabular}{|l|l|l|l|l|}
\hline No & Nama Perusahaan & \multicolumn{3}{|c|}{ Tahun } \\
\hline \multicolumn{2}{|l|}{} & 2014 & 2015 & 2016 \\
\hline $\mathbf{1}$ & PT. Eastrn Modern Apparel & Sehat & Sehat & Sehat \\
\hline $\mathbf{2}$ & PT. Century Textile Industri & Sehat & Sehat & Sehat \\
\hline $\mathbf{3}$ & PT. Panisia Indosyntex & Sehat & Sehat & Grey Area \\
\hline
\end{tabular}

Pada tabel V dapat dilihat bahwa prediksi kebangkrutan di PT. Eastern Modern Apparel mengalami perubahan. Hal ini terjadi pada tahun 2016 dimana hasilnya mendekati ke zona grey area. Hasil dari pengolahan tersebut membuktikan bahwa kejadian pada tahun 2016 berdampak pada pemberhentian beberapa pegawai ternyata di akibatkan oleh penurunan kondisi perusahaan. Jika perusahaan mengalami hal seperti ini maka akan mendorong pada terjadinya kesulitan keuangan dan jika keadaan tersebut terus berlanjut maka perusahaan akan mengalami kebangkrutan.

\section{PEMBAHASAN}

Berdasarkan tabel II perusahaan garmen pada tahun 2014 yaitu PT. Eastern Modern Apparel, PT. Century Textile Industri, PT. Panisia Indosyntex berada dalam kondisi yang baik artinya tidak terjadinya financial disstres $(>2,675)$.

Working capital to total asset ratio (X1) digunakan untuk mengukur likuiditas terhadap total kapitalisasinya atau untuk mengukur kemampuan perusahaan dalam memenuhi kewajiban jangka pendek. PT. Panisia Indosyntex mendapatkan nilai dalam rasio X1 sebesar 0,493 dan merupakan perusahaan dengan rasio terendah yang mengindikasikan bahwa tingkat likuiditasnya paling rendah di antara perusahaanperusahaan lain. PT. Eastern Modern Apparel mendapatkan nilai tertinggi dalam rasio $\mathrm{X} 1$ sebesar 0,611 artinya perusahaan mampu 
mengelola dan memenuhi kewajiban jangka pendeknya.

Retained earning to total asset ratio (X2) digunakan untuk mengukur profitabilitas kumulatif. Umur perusahaan berpengaruh terhadap rasio tersebut karena semakin lama perusahaan beroperasi memungkinkan untuk memperlancar akumulasi laba ditahan. Hal ini menyebabkan perusahaan yang masih relatif muda pada umumnya akan menunjukkan hasil rasio yang rendah,kecuali yang labanya sangat besar pada masa awal berdirinya. PT. Panisia Indosyntex tahun ini memliki rasio (X2) yaitu sebesar 0,255, artinya bahwa selama itu pula perusahaan tidak pernah membukukan laba ditahan atau selalu mengakumulasikan rugi ditahan. Hal ini yang mengindikasikan bahwa kemampuan asetnya untuk memperoleh laba ditahan sangatlah rendah bila dibandingkan dengan perusahaan perusahaan lainnya. PT. Eastern Modern Apparel dalam rasio X2 merupakan perusahaan yang memiliki nilai tertinggi yaitu 0,382 .

Earning before interest and taxes to total asset ratio (X3) mengukur kemampuan perusahaan dalam menghasilkan laba dari aset yang digunakan. Semakin kecil tingkat profitabilitas berarti semakin tidak efisien dan tidak efektif perusahaan menggunakan keseluruhan aset di dalam menghasilkan laba usaha begitu juga sebaliknya. Perusahaan dengan rasio X3 terendah adalah PT. Panisia Indosyntex sebesar 0,507. Hal ini menunjukkan bahwa pihak manajemen tidak dapat mengelola assetnya secara efektif jika dibandingkan dengan PT. Eastern Modern Apparel dan PT. Century Textile Industri. Perusahaan dengan rasio tertinggi adalah PT. Eastern Modern Apparel sebesar 0.562.

Market value equity to book value total debt ratio (X4) digunakan untuk mengukur seberapa banyak aset perusahaan dapat turun nilainya sebelum jumlah hutang lebih besar dari pada asetnya dan perusahaan mengalami kesulitan keuangan. Perusahaan dengan X4 terendah tahun ini adalah PT. Eastern Modern Apparel sebesar 0,001 . Hal ini mengindikasikan bahwa perusahaan tersebut mengakumulasikan lebih banyak hutang dari pada modal sendiri dibandingkan dengan perusahaan-perusahaan lain. Perusahaan dengan rasio tertinggi adalah PT. Century Textile Industri dengan nilai 0,020. Hal ini berarti bahwa perusahaan tersebut mengakumulasikan hutang terhadap modal sendiri lebih rendah bila dibandingkan dengan perusahaan-perusahaan lain.

Sales to total asset ratio (X5) mengukur kemampuan manajemen dalam menggunakan aset untuk menghasilkan penjualan. Perusahaan dengan X5 terendah adalah PT. Panisia
Indosyntex dengan nilai rasio X5 sebesar 0,714 artinya perusahaan tersebut diindikasikan kurang efektif menggunakan aset untuk meningkatkan penjualan dibandingkan dengan perusahaanperusahaan lainnya. Dan rasio tertinggi tahun ini adalah PT. Century Textile Industri dengan nilai rasio X5 sebesar 0,991. Hal ini mengindikasikan bahwa PT. Century Textile Industri mampu menggunakan aset secara efektif untuk meningkatkan penjualan pada tahun ini.

Berdasarkan tabel III perusahaan garmen pada tahun 2015 yaitu PT. Eastern Modern Apparel, PT. Century Textile Industri, PT. Panisia Indosyntex berada dalam kondisi yang baik artinya tidak terjadinya financial disstres $(>2,675)$.

Pada tahun 2015 PT. Panisia Indosyntex mendapatkan nilai dalam rasio X1 sebesar 0,400 . dan merupakan perusahaan dengan rasio terendah yang mengindikasikan bahwa tingkat likuiditasnya paling rendah di antara perusahaanperusahaan lain. PT. Century Textile Industri mendapatkan nilai tertinggi dalam rasio $\mathrm{X} 1$ sebesar 0,526 artinya perusahaan mampu mengelola dan memenuhi kewajiban jangka pendeknya.

Retained earning pada tahun 2015 PT. Panisia Indosyntex tahun ini memliki rasio (X2) yaitu sebesar 0,340, artinya bahwa selama itu pula perusahaan tidak pernah membukukan laba ditahan atau selalu mengakumulasikan rugi ditahan. Hal ini yang mengindikasikan bahwa kemampuan asetnya untuk memperoleh laba ditahan sangatlah rendah bila dibandingkan dengan perusahaan perusahaan lainnya. PT. Eastern Modern Apparel dalam rasio X2 merupakan perusahaan yang memiliki nilai tertinggi yaitu 0,558 .

Perusahaan dengan rasio X3 terendah adalah PT. Eastern Modern Apparel sebesar 0,397. Hal ini menunjukkan bahwa pihak manajemen tidak dapat mengelola asetnya secara efektif jika dibandingkan dengan PT. Panisia Indosyntex dan PT. Century Textile Industri. Perusahaan dengan rasio tertinggi adalah PT. Century Textile Industri sebesar 0.559 .

Perusahaan dengan $\mathrm{X} 4$ terendah tahun ini adalah PT. Panisia Indosyntex sebesar 0,008. Hal ini mengindikasikan bahwa perusahaan tersebut mengakumulasikan lebih banyak hutang daripada modal sendiri dibandingkan dengan perusahaanperusahaan lainya. Perusahaan dengan rasio tertinggi adalah PT. Century Textile Industri dengan nilai 0,023. Hal ini berarti bahwa perusahaan tersebut mengakumulasikan hutang terhadap modal sendiri lebih rendah bila dibandingkan dengan perusahaan-perusahaan lain. 
Sales to total asset ratio (X5) Perusahaan dengan X5 terendah adalah PT. Eastern Modern Apparel dengan nilai rasio X5 sebesar 0,563 artinya perusahaan tersebut diindikasikan kurang efektif menggunakan aset untuk meningkatkan penjualan dibandingkan dengan perusahaanperusahaan lainnya. Dan rasio tertinggi tahun ini adalah PT. Century Textile Industri dengan nilai rasio X5 sebesar 0,831 . Hal ini mengindikasikan bahwa PT. Century Textile Industri mampu menggunakan aset secara efektif untuk meningkatkan penjualannya di tahun ini.

Berdasarkan tabel IV perusahaan garmen pada tahun 2016 yaitu PT. Eastern Modern Apparel, PT. Century Textile Industri, PT. Panisia Indosyntex berada dalam kondisi yang baik artinya tidak terjadinya financial disstres $(>2,675)$.

Akan tetapi PT. Panisia Indosyntex pada 2016 masuk ke dalam grey area karena mendapatkan nilai $\mathrm{Z}$ sebesar 2,27 hal ini berarti perusahaan berpotensi mengalami finansial distress $(2,675$ - 1,81). Berikut dapat dijelaskan indikator financial distress dari masing-masing rasio keuangan metode Altman Z-Score.

PT. Panisia Indosyntex mendapatkan nilai dalam rasio $\mathrm{X} 1$ sebesar 0,283 dan merupakan perusahaan dengan rasio terendah yang mengindikasikan bahwa tingkat likuiditasnya paling rendah di antara perusahaan-perusahaan lain. PT. Century Textile Industri mendapatkan nilai tertinggi dalam rasio X1 sebesar 0,498 artinya perusahaan mampu mengelola dan memenuhi kewajiban jangka pendeknya.

Retained earning to total asset ratio (X2) PT. Panisia Indosyntex tahun ini memiliki rasio (X2) yaitu sebesar 0,313 , artinya bahwa selama itu pula perusahaan tidak pernah membukukan laba ditahan atau selalu mengakumulasikan rugi ditahan. Hal ini yang mengindikasikan bahwa kemampuan asetnya untuk memperoleh laba ditahan sangatlah rendah bila dibandingkan dengan perusahaan perusahaan lainnya. PT. Eastern Modern Apparel dalam rasio X2 merupakan perusahaan yang memiliki nilai tertinggi yaitu 0,658 .

Perusahaan dengan rasio X3 terendah adalah PT. Panisia Indosyntex sebesar 0,292. Hal ini menunjukkan bahwa pihak manajemen tidak dapat mengelola asetnya secara efektif jika dibandingkan dengan PT. Eastern Modern Apparel dan PT. Century Textile Industri. Perusahaan dengan rasio tertinggi adalah PT. Century Textile Industri sebesar 0.543 .

Perusahaan dengan X4 terendah tahun ini adalah PT. Panisia Indosyntex sebesar 0,008. Hal ini mengindikasikan bahwa perusahaan tersebut mengakumulasikan lebih banyak hutang daripada

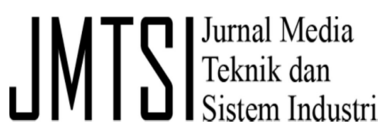

modal sendiri dibandingkan dengan perusahaanperusahaan lain. Perusahaan dengan rasio tertinggi adalah PT. Century Textile Industri dengan nilai 0,039. Hal ini berarti bahwa perusahaan tersebut mengakumulasikan hutang terhadap modal sendiri lebih rendah bila dibandingkan dengan perusahaan-perusahaan lain.

Perusahaan dengan X5 terendah adalah PT. Eastern Modern Apparel dengan nilai rasio X5 sebesar 0,445 artinya perusahaan tersebut diindikasikan kurang efektif menggunakan aset untuk meningkatkan penjualan dibandingkan dengan perusahaan-perusahaan lainnya. Dan rasio tertinggi tahun ini adalah PT. Century Textile Industri dengan nilai rasio X5 sebesar 0,854. Hal ini mengindikasikan bahwa PT. Century Textile Industri mampu menggunakan aset secara efektif untuk meningkatkan penjualannya di tahun ini.

Berikut ini merupakan trend kondisi keuangan yang terjadi pada perusahaan garmen yaitu berdasarkan metode Altman Z-score.

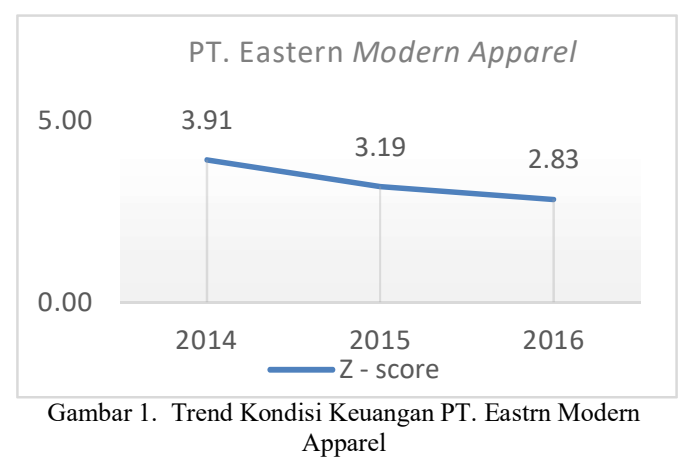

Berdasarkan gambar 1 dapat dilihat pada tahun 2014 PT. Eastern Modern Apparel tidak mengalami financial distress. Hal ini dibuktikan oleh hasil perhitungan dari metode Almant Zscore memperoleh hasil $\mathrm{Z}$ sebesar 3,91 ( $\mathrm{Z}>$ 2,675).

Pada tahun 2015 berdasarkan hasil perhitungan dengan menggunakan metode Altman Z-score PT. Eastern Modern Apparel memperoleh hasil Z sebesar 3,19 perusahaan tidak mengalami financial distress $(\mathrm{Z}>2,675)$.

TABEL VI

Persentase Kenaikan dan Penurunan Rasio ALTMAN Z-SCORE PT. EASTERN MODERN APPAREL Altman Z- score PT EMA

\begin{tabular}{c|c|c|c|c|c|c|c|c|c|c}
\multicolumn{10}{c}{ Altman Z-score PT EMA } \\
\hline Tahun & $X 1$ & $\%$ & $X 2$ & $\%$ & $X 3$ & $\%$ & $X 4$ & $\%$ & $X 5$ & $\%$ \\
\hline 2015 & 0,438 & $-17 \%$ & 0,558 & $18 \%$ & 0,397 & $-16 \%$ & 0,012 & $1 \%$ & 0,563 & $-23 \%$ \\
\hline
\end{tabular}

Working capital/total assets X1

Penurunan X1 yang terjadi pada tahun 2015 sebesar $17 \%$. Hal ini membuat perusahaan harus selalu mengevaluasi pengolahan modal kerja 
setiap periodenya agar terhindar dari penurunan nilai secara terus menerus yang akan mempengaruhi pada kondisi keuangan perusahaan.

Earnings before interest and taxes/total assets X3

Kenaikan Retained earnings/total assets $\mathrm{X} \neg 2$ yang terjadi pada tahun 2015 sebesar 18\%. Hal ini terjadi karena penurunan yang berasal dari Earnings before interest and taxes/total assets X3 sebesar $16 \%$.

Market value of equity/book value of total debt X4

Kenaikan X4 di tahun 2015 sebesar 1\%. Hal ini disebabkan adanya penurunan total kewajiban perusahaan yang mampu memenuhi kewajiban jangka pendek dan kewajiban jangka panjang. Sales/total assets X5

Penurunan Sales/total assets X5 pada tahun 2015 sebesar 23\% disebabkan oleh adanya penurunan pada penjualan. Hal ini mengakibatkan perusahaan harus meningkatkan pemanfaatan aset yang ada untuk peningkatan penjualan perusahaan.

Pada tahun 2016 berdasarkan perhitungan menggunakan metode Altman Z-score, PT. Eastrn Modern Apparel memperoleh nilai Z sebesar 2,83 perusahaan tidak mengalami financial distress $(Z>2,675)$.

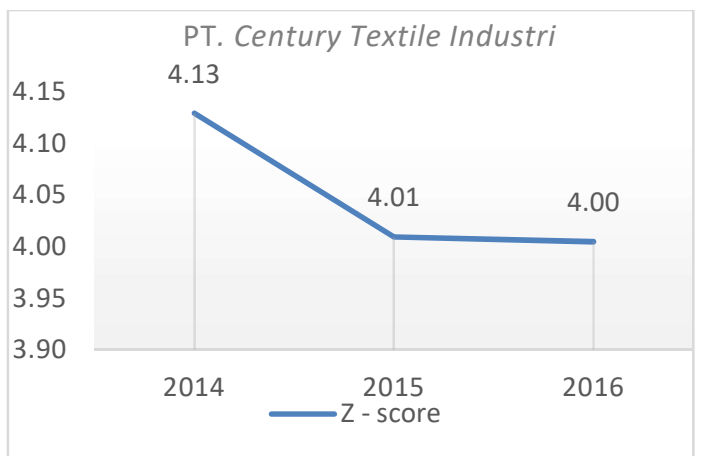

Gambar 2. Tren Kondisi Keuangan PT. Century Textile Industri

Berdasarkan gambar 2 dapat dilihat pada tahun 2014 PT. Century Textile Industri tidak mengalami financial distress. Hal ini dibuktikan oleh hasil perhitungan dari metode Almant Zscore memperoleh hasil $\mathrm{Z}$ sebesar 4,13 ( $\mathrm{Z}>$ 2,675).

Pada tahun 2015 berdasarkan hasil perhitungan dengan menggunakan metode Altman Z-score PT. Century Textile Industri memperoleh hasil $\mathrm{Z}$ sebesar 4,01. Sehingga perusahaan tidak mengalami financial distress $(Z>2,675)$.
TABEL VII

Persentase Kenaikan dan Penurunan Rasio ALTMAN Z-SCORE PT. CENTURY TEXTILE INDUSTRI

\begin{tabular}{c|c|c|c|c|c|c|c|c|c|c|}
\hline \multicolumn{10}{|c|}{ Altman Z- score PT CENTEX } \\
\hline Tahun & $\mathrm{X} 1$ & $\%$ & $\mathrm{X} 2$ & $\%$ & $\mathrm{X} 3$ & $\%$ & $\mathrm{X} 4$ & $\%$ & $\mathrm{X} 5$ & $\%$ \\
\hline 2015 & 0,526 & $.7 \%$ & 0,492 & $15 \%$ & 0,559 & $.5 \%$ & 0,023 & $0 \%$ & 0,831 & $.8 \%$ \\
\hline
\end{tabular}

Working capital/total assets X1

Penurunan X1 yang terjadi pada tahun 2015 sebesar 7\% . Hal ini membuat perusahaan harus selalu mengevaluasi pengolahan modal kerja setiap periodenya agar terhindar dari penurunan nilai secara terus menerus yang akan mempengaruhi pada kondisi keuangan perusahaan.

Earnings before interest and taxes/total assets X3

Kenaikan Retained earnings/total assets $X \neg 2$ yang terjadi pada tahun 2015 sebesar $15 \%$. Hal ini terjadi karena penurunan yang berasal dari Earnings before interest and taxes/total assets X3 sebesar 5\% .

Market value of equity/book value of total debt $\mathrm{X} 4$

Stabilitas dari X4 di tahun 2015. Hal ini di sebabkan perusahaan yang mampu memenuhi kewajiban jangka pendek dan kewajiban jangka panjang.

Sales/total assets X5

Penurunan Sales/total assets X5 pada tahun 2015 sebesar 8\% disebabkan oleh adanya penurunan pada penjualan. Hal ini mengakibatkan perusahaan harus meningkatkan pemanfaatan asset yang ada untuk peningkatan penjualan perusahaan.

Pada tahun 2016 berdasarkan perhitungan menggunakan metode Altman Z-score, PT. Century Textile Industri memperoleh nilai $Z$ sebesar 4,00 perusahaan tidak mengalami financial distress $(Z>2,675)$ perusahaan di katakan sehat.

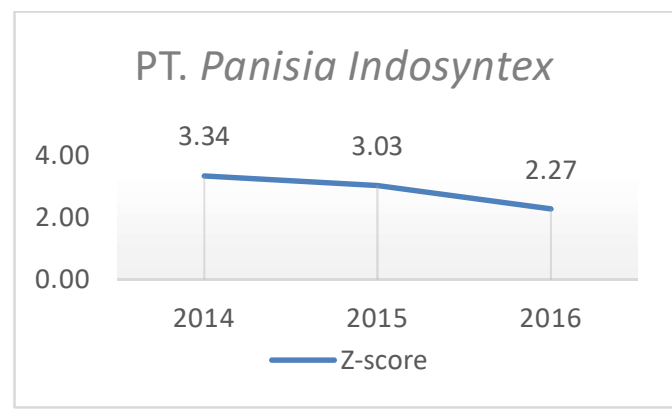

Gambar 3. Tren Kondisi Keuangan PT. Panisia Indosyntex

Berdasarkan gambar 3 dapat dilihat pada tahun 2014 PT. Panisia Indosyntex tidak mengalami financial distress. Hal ini dibuktikan oleh hasil perhitungan dari metode Almant Z- 
score memperoleh hasil $\mathrm{Z}$ sebesar 3,34 ( $\mathrm{Z}>$ 2,675).

Pada tahun 2015 berdasarkan hasil perhitungan dengan menggunakan metode Altman Z-score PT. Panisia Indosyntex memperoleh hasil $\mathrm{Z}$ sebesar 3,03 perusahaan tidak mengalami financial distress $(Z>2,675)$.

TABEL VIII

Persentase Kenaikan dan Penurunan Rasio

\begin{tabular}{c|c|c|c|c|c|c|c|c|c|c|}
\multicolumn{10}{c|}{ AltmanZ- score PT SYTEX } \\
\hline Tahun & $\times 1$ & $\%$ & $\times 2$ & $\%$ & $\times 3$ & $\%$ & $\times 4$ & $\%$ & $\times 5$ & $\%$ \\
\hline 2015 & 0,400 & $-9 \%$ & 0,340 & $9 \%$ & 0,404 & $-10 \%$ & 0,008 & $0 \%$ & 0,735 & $2 \%$ \\
\hline \multicolumn{10}{c|}{ ALTMAN Z-SCORE PT. SYNTEX }
\end{tabular}

\section{Working capital/total assets X1}

Penurunan X1 yang terjadi pada tahun 2015 sebesar 9\%. Hal ini membuat perusahaan harus selalu mengevaluasi pengolahan modal kerja setiap periodenya agar terhindar dari penurunan nilai secara terus menerus yang akan mempengaruhi pada kondisi keuangan perusahaan.

Earnings before interest and taxes/total assets X3

Kenaikan Retained earnings/total assets $X \neg 2$ yang terjadi pada tahun 2015 sebesar $9 \%$ hal ini terjadi karena penurunan yang berasal dari Earnings before interest and taxes/total assets X3 sebesar $10 \%$.

Market value of equity/book value of total debt X4

Stabilitas dari X4 di tahun 2015. Hal ini di sebabkan perusahaan yang mampu memenuhi kewajiban jangka pendek dan kewajiban jangka panjang.

Sales/total assets X5

Penurunan Sales/total assets X5 pada tahun 2015 sebesar 2\% di sebabkan oleh adanya penurunan pada penjualan. Hal ini mengakibatkan perusahaan harus meningkatkan pemanfaatan aset yang ada untuk peningkatan penjualan perusahaan.

Pada tahun 2016 berdasarkan perhitungan menggunakan metode Altman Z-score, PT. Panisia Indosyntex memperoleh nilai $Z$ sebesar 2,27 perusahaan tidak mengalami financial distress namun berada pada grey area $(Z=1,81$ 2,675).

Hasil penelitian menyatakan bahwa berdasarkan metode Altman Z -score ada satu perusahaan yang dinyatakan berada pada posisi grey area.

Berdasarkan tabel IX maka dapat disimpulkan prediksi financial distress selama 2014 - 2016. Sebagian besar berada pada kondisi tidak mengalami kesulitan keuangan (Non

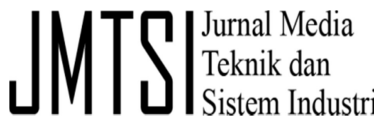

Finacial Distress). Hal ini dilihat dari perbedaan pada setiap rasio yang dijadikan indikator juga sangatlah berpengaruh, terlihat bahwa metode Altman $\mathrm{Z}$-score lebih ketat dalam menilai tingkat kebangkrutan. Pengukuran tersebut bisa dilihat dari pembagian zona yaitu : Non Financial Distress ( $\mathrm{Z}>2,675)$, Grey Area $(\mathrm{Z}=1,81$ 2,675), Financial Distress $(Z<1,81)$.

TABEL IX

Hasil Prediksi FinANCial Distress Metode Altman Z SCORE

\begin{tabular}{c|c|c|c|}
\multirow{2}{*}{ Tahun } & \multicolumn{3}{|c|}{ Altman Z-score } \\
\cline { 2 - 4 } & Non Financial Distress & Grey Area & Financial Distress \\
\hline 2014 & 3 & 0 & 0 \\
\hline 2015 & 3 & 0 & 0 \\
\hline 2016 & 2 & 1 & 0 \\
\hline
\end{tabular}

\section{KESIMPULAN}

Kondisi keuangan PT. Eastern Modern Apparel, PT. Panisia Indosyntex, PT. Century Textile Industri terus menurun dari tahun 2014 2016 jika diuji menggunakan metode Altman Zscore namun masih dalam zona sehat. Secara khusus PT. Panisia Indosyntex mengalami kondisi yang paling buruk pada tahun 2016 dengan mencapai hasil terendah dan berada pada posisi grey area.

Model Z- Score Altman dapat memprediksi trend kondisi keuangan perusahaan di bidang garmen di Indonesia. Pada tahun 2014 dan 2015 ketiga perusahaan yang bergerak dalam bidang garmen berada dalam zona sehat. Hal tersebut di buktikan dengan kesemua hasil yang menunjukkan nilai $>2,675$ yang merupakan batasan kategori perusahaan yang sehat. Akan tetapi pada tahun 2016 hanya 2 perusahaan yang mampu bertahan dalam posisi sehat sedangkan 1 perusahaan mengalami penurunan ke dalam kategori grey area yang bisa dikatakan mendekati financial disstress

\section{UCAPAN TERIMA KASIH}

Penulis ingin menyampaikan rasa terima kasih yang sebesar-besarnya kepada:

1. Allah SWT yang telah memberikan rahmat dan karunia serta nikmat yang tidak terhingga serta kesehatan yang terus diberikan sehingga penulis dapat menyelesaikan laporan ini.

2. Kedua orang tua dan keluarga yang senantiasa memberikan dukungan selama penyusunan laporan ini, terutama dukungan doa dan motivasi.

3. Bapak Bramantiyo Eko Putro S.Mb.,MT selaku dosen pembimbing yang senantiasa memberikan motivasi, ilmu, masukan, saran dan perbaikan terhadap penelitian yang dilakukan. 
4. Bapak Akhmad Sutoni,ST. Dan Dr.H.Ali Subhan ST.,SH.,MT.,MKn. Selaku koordinator dan dosen wali yang memberikan arahan dalam penyusunan kerja praktek ini.

5. Bapak Deri selaku pimpinan (HRD) PT. Eastern Modern Apparel yang telah memberikan banyak bantuan dalam penyusunan laporan kerja praktek ini.

6. Teman-teman Teknik Industri 2013 yang sangat luar biasa, yang selalu saling memberi motivasi dan menguatkan dalam proses penyusunan laporan ini.

7. Bapak Dodi Jumyati ST. dan Bapak Ismail Saleh ST. Yang membantu membimbing dalam menyusun laporan ini.

8. Teman-teman HMTI Unsur dan Ikatan Mahasiswa Teknik Industri Indonesia (zona Jawa Barat) yang selalu saling memberi motivasi dan menguatkan dalam proses penyusunan laporan ini

9. Pihak-pihak lain yang tidak dapat disebutkan satu persatu yang telah membantu sehingga terselesaikannya laporan kerja praktek ini.

\section{REFERENSI}

[1] Husnan S, Muhammad S. (2000). Studi Kelayakan Proyek. Yogyakarta : Unit Penerbit dan Percetakan AMP YKPN.

[2] Umar, (2000), "Metode Penelitian Untuk Skripsi dan Tesis Bisnis", Jakarta, Raja Grafindo Persada.

[3] Hadi. (2008). "Pemilihan Prediktor Delisting Terbaik Perbandingan Antara Model The Zmijewski Model, The Altman Model, dan The Springate Model”. Jurnal Akuntansi dan Keuangan. Yogyakarta.

[4] Hariani. 2009. Analisis Potensi Kebangkrutan dengan Menggunakan Model Altman pada Perusahaan Food dan Beverage Go Public di Bursa Efek Indonesia. Universitas Lampung. Lampung.

[5] Fakhrurozie. 2007. Analisis Pengaruh Kebangkrutan Bank dengan Metode Altman Z-Score terhadap Harga Saham Perusahaan Perbankan di Bursa Efek Jakarta Universitas Negeri Semarang. Semarang

Adnan. 2000. Analisis Tingkat Kesehatan untuk Memprediksi Potensi Kebangkrutan dengan Pendekatan Altman. JAAI Volume 4 No. 2: 137-142. 